\title{
Prothrombin 3'end Gene Variants in Patients With Sporadic Colon Adenocarcinoma
}

\author{
MARIJA CUMBO ${ }^{1}$, BRANKO TOMIC ${ }^{1}$, SOFIJA DUNJIC ${ }^{1}$, TAMARA JOVANOVIC ${ }^{1}$, \\ MAJA GVOZDENOV ${ }^{1}$, IVA PRUNER ${ }^{1}$, GORANA ARALICA ${ }^{2,3}$, \\ SANJA KAPITANOVIC ${ }^{4}$, TAMARA CACEV ${ }^{4}$ and VALENTINA DJORDJEVIC ${ }^{1}$ \\ ${ }^{1}$ Institute of Molecular Genetics and Genetic Engineering, University of Belgrade, Belgrade, Serbia; \\ ${ }^{2}$ University Hospital Dubrava, Zagreb, Croatia; \\ ${ }^{3}$ Medical School University of Zagreb, Zagreb, Croatia; \\ ${ }^{4}$ Rudjer Boskovic Institute, Zagreb, Croatia
}

\begin{abstract}
Background/Aim: Thrombin plays significant roles in various types of cancer. However, the expression levels of prothrombin, the thrombin precursor, in cancer remain unclear. Variants of the 3'end of the prothrombin gene lead to increased prothrombin expression. This study aimed to analyze prothrombin 3'end gene variants in colon tumor and adjacent normal tissue samples. Materials and Methods: The study group consisted of 93 patients suffering from colon adenocarcinoma. The 3'end of the prothrombin gene was analyzed by DNA sequencing. Results: Three variants, all previously associated with increased prothrombin expression were detected. Frequency of the FII 19911 allele was $46.77 \%$ and $47.85 \%$ in tumor and normal tissue, respectively. For the FII 20210A allele, the detected frequencies were $2.15 \%$ and $1.61 \%$, respectively. The frequency of the FII c.1824T allele was $0.54 \%$ in both tissues. Four patients showed different genotypes in tumor and normal tissue. Conclusion: Prothrombin 3' end gene variants may play a role in colorectal cancer.
\end{abstract}

Colorectal cancer (CRC) is the third most commonly diagnosed cancer in males and the second in females globally (1). Adenocarcinoma, a cancer starting in mucous glands, is the most common type of CRC, accounting for about $95 \%$ of CRC cases (2). Approximately $75 \%$ of CRC cases are sporadic, and occur without a family history of the

Correspondence to: Marija Cumbo, MSc, Vojvode Stepe 444A, P.O. Box 23, 11010 Belgrade, Serbia. Tel: +381 113976658, Fax: +381 113975808, e-mail: marijacumbo@imgge.bg.ac.rs

Key Words: Colon adenocarcinoma, normal adjacent tissue, prothrombin, tumor, 3 'end gene variants. disease (3). Despite the extensive research, the molecular mechanisms of CRC are still not fully elucidated.

A close relationship between coagulation and cancer has been recognized for more than a century. In the context of $\mathrm{CRC}$, there is growing incidence that thrombotic disorders are associated with significant mortality and morbidity (4). Studies have shown increased levels of coagulation factors and markers in cancer patients, thus explaining the presence of hypercoagulable state $(5,6)$. The recent data suggest that coagulation factors, particularly thrombin, may also have important roles in carcinogenesis.

Thrombin, a serine protease, plays a pivotal role in hemostasis, involving both pro- and anti-coagulant activities (7). Besides its central role in hemostasis, evidence has shown that thrombin can affect different processes in malignant cells through protease activated receptors (PAR), including promotion of cell proliferation and invasion (8). In addition to that, thrombin has been shown to promote tumor angiogenesis, which is one of the essential processes in tumor growth and metastasis $(9,10)$.

The precursor of thrombin, prothrombin, is predominantly synthesized in the liver and secreted into the bloodstream in the form of zymogen (11). The 3' untranslated region of the prothrombin gene has a noncanonical structure, which is susceptible to gain-of-function variants that can lead to increased prothrombin expression, and consequently to increased risk of thrombosis (12).

It is documented that certain colon cancer cells are capable of prothrombin expression (13), but the influence of the 3 ' end of the prothrombin gene variants on cancer and the complex genotype-phenotype correlations in colon cancer have been very poorly studied.

In this study we aimed to analyse the 3 ' end of the prothrombin gene in tumor and normal tissues adjacent to the tumor from patients with colon adenocarcinoma. 
Table I. Clinicopathological characteristics of patients with colon adenocarcinoma.

\begin{tabular}{lcc}
\hline & No. of cases & $\%$ of cases \\
\hline $\begin{array}{l}\text { Total number } \\
\text { Gender }\end{array}$ & 93 & 100.0 \\
$\quad$ Male & 54 & 58.1 \\
$\quad$ Female & 39 & 41.9 \\
Dukes stage & & \\
A & 18 & 19.4 \\
B & 26 & 28 \\
C & 43 & 46.2 \\
D & 6 & 6.5 \\
Tumor size & & \\
$\leq 5$ cm & & 59.8 \\
$>5$ cm & 49 & 40.2 \\
Histological grade (differentiation) & 33 & \\
Poor & & 10.1 \\
Moderate & 7 & 62.3 \\
Well & 43 & 27.5 \\
\hline
\end{tabular}

$\dagger$ data available for 82 patients; $\ddagger$ data available for 69 patients.

\section{Materials and Methods}

DNA samples. Colon tumor and normal adjacent tissue (NAT) samples were obtained from the Croatian Tumor Bank (14). Samples were collected during routine surgery performed in 93 patients with sporadic colon adenocarcinoma, all histopathologically characterized. To determine the proportion of tumor cells, each sample was examined by routine hematoxylin-eosin staining. Fresh tissue samples were frozen in liquid nitrogen and stored at $-80^{\circ} \mathrm{C}$ until use. DNA extraction from tumor and normal tissue was performed using proteinase $\mathrm{K}$ digestion and phenol chloroform extraction (15).

Written informed consent was obtained from all patients included in the study. The study was approved by the Ethics Committee of Clinical Hospital Dubrava, Zagreb (approval was obtained on 27th Apr. 2016) and was performed in accordance with the ethical standards of the Helsinki Declaration.

Sequencing of the 3' end of the prothrombin gene. The $715 \mathrm{bp}$ fragment located within the $3^{\prime}$ end of the prothrombin gene (including the last intron and exon, 3' untranslated region and 3' flanking region) was amplified by polymerase chain reaction (PCR) using 5'GGAAACGAGGGGATGCCTGT-3' and 5'-CCTGCCATCTTTCCT CTCAC-3' primers. Amplification conditions were: initial denaturation at $95^{\circ} \mathrm{C}$ for $5 \mathrm{~min}, 39$ cycles at $95^{\circ} \mathrm{C}$ for $1 \mathrm{~min}, 61^{\circ} \mathrm{C}$ for $1 \mathrm{~min}$ and $72^{\circ} \mathrm{C}$ for $1 \mathrm{~min}$, and final elongation at $72^{\circ} \mathrm{C}$ for $10 \mathrm{~min}$. Generated fragments were sequenced with 5'-GAATAGCACTGGGAGCATTGA3' and 5'-TCTAGAAACAGTTGCCTGGC-3' primers using the BigDye $^{\mathrm{TM}}$ Terminator Version 3.1 Ready Reaction Kit (Applied Biosystems, Foster City, CA, USA) according to the manufacturer's protocol, on a 3130 Genetic Analyzer (Applied Biosystems).

Haplotype analysis. Prothrombin DNA fragment of interest (715 bp) was cloned into the pJET1.2/blunt vector, using the CloneJet PCR Cloning Kit according to the manufacturer's protocol (Thermo
Table II. Genotype combinations found in patients with colon adenocarcinoma.

\begin{tabular}{|c|c|c|c|}
\hline \multicolumn{3}{|c|}{ Gene variants in 3' end of prothrombin gene } & \multirow{2}{*}{$\begin{array}{c}\text { Number of } \\
\text { patients } \\
\mathrm{N}(\%)\end{array}$} \\
\hline FII A19911G & FII G20210A & FII c. $1824 \mathrm{C}>\mathrm{T}$ & \\
\hline AG & GG & $\mathrm{CC}$ & $40(43.0)^{\dagger}$ \\
\hline GG & GG & $\mathrm{CC}$ & $23(24.7)$ \\
\hline AA & GA & $\mathrm{CC}$ & $1(1.1)$ \\
\hline AG & GA & $\mathrm{CC}$ & $2(2.2)^{\ddagger}$ \\
\hline AG & GG & $\mathrm{CT}$ & $1(1.1)$ \\
\hline $\mathrm{AA}$ & GG & $\mathrm{CC}$ & $26(28.0)$ \\
\hline
\end{tabular}

three patients had different genotypes in tumor tissue compared to normal tissue; $\ddagger$ one patient had different genotype in tumor tissue compared to normal tissue.

Scientific, Waltham, MA, USA). After cloning, plasmids were extracted using Pure Link HQ Mini Plasmid Purification Kit (Invitrogen, Carlsbad, CA, USA). The cloned fragments were then sequenced with 5'-ATAGCACTGGGAGCATTGAAGC-3' and 5'GGATGGGAAATATGGCTTCTAC-3' primers using the BigDye ${ }^{\mathrm{TM}}$ Terminator Version 3.1 Ready Reaction Kit (Applied Biosystems) according to the manufacturer's protocol, on a 3130 Genetic Analyzer (Applied Biosystems).

\section{Results}

Analysis of the 3' end of the prothrombin gene on tumor and NAT tissues was performed on samples from 93 patients (54 male and 39 female) with colon adenocarcinoma. Average age of patients was 66 years (range $=34-90$ years). Clinicopathological data of patients are listed in Table I.

In both, tumor and normal colon tissues, three prothrombin variants were detected: FII A19911G (FII c.*1726-59A>G), FII G20210A (FII c.*97G>A), and FII c.1824C $>$ T.

Frequency of the allele FII $19911 \mathrm{G}$ was $46.77 \%$ in tumor and $47.85 \%$ in NAT, of the allele FII 20210A was $2.15 \%$ in tumor and $1.61 \%$ in NAT, and of FII c. $1824 \mathrm{~T}$ was $0.54 \%$ in both tissues.

The frequency of the FII 19911AG genotype in tumor tissue and NAT was $41.9 \%$ and $46.2 \%$, respectively, while the frequency of the FII 19911GG genotype in tumor tissue and NAT was $25.8 \%$ and $24.7 \%$, respectively. The frequency of the heterozygous genotype for FII 20210GA in tumor tissue and NAT was $2.2 \%$ and $3.2 \%$, respectively, while the frequency of the FII 20210AA genotype in tumor tissue was $1.1 \%$, but it was not detected in normal tissue. Combinations of genotypes found in patients are shown in Table II.

Differences in genotypes in tumor and normal tissue were detected in four patients. Two patients were non-carriers (tumor tissue)/heterozygous (NAT) and one patient was homozygous (tumor tissue)/heterozygous (NAT) for the FII A19911G variant only. One patient was a carrier of different 
Table III. Clinicopathological data for patients with colon adenocarcinoma carrying different genotypes in tumor tissues compared to NAT.

\begin{tabular}{|c|c|c|c|c|c|c|c|c|c|}
\hline & \multicolumn{4}{|c|}{ Gene variants in $3^{\prime}$ end of prothrombin gene } & \multicolumn{5}{|c|}{ Tumor characteristics } \\
\hline & \multicolumn{2}{|c|}{ FII A19911G } & \multicolumn{2}{|c|}{ FII G20210A } & \multirow{2}{*}{$\begin{array}{c}\text { Age } \\
\text { (years) }\end{array}$} & \multirow[t]{2}{*}{ Gender } & \multirow[t]{2}{*}{ Dukes } & \multirow[t]{2}{*}{ Grade } & \multirow{2}{*}{$\begin{array}{c}\text { Tumor } \\
\text { size }(\mathrm{cm})\end{array}$} \\
\hline & Tumor & Normal & Tumor & Normal & & & & & \\
\hline 1 & AA & AG & GG & GG & 75 & M & $\mathrm{C}$ & 3 & 4 \\
\hline 2 & AA & AG & GG & GG & 68 & $\mathrm{~F}$ & $\mathrm{C}$ & 2 & 4 \\
\hline 3 & GG & $\mathrm{AG}$ & GG & GG & 71 & M & A & 2 & 4 \\
\hline 4 & $\mathrm{AA}$ & AG & $\mathrm{AA}$ & GA & 76 & $\mathrm{M}$ & $\mathrm{C}$ & 1 & 5 \\
\hline
\end{tabular}

All four patients did not carry the FII c.1824C $>$ T. M: Male; F: female; NAT: normal adjacent tissue.

tissue genotypes for FII G20210A - homozygous (tumor tissue)/heterozygous (NAT), and for the FII A19911G variant - non-carrier (tumor tissue)/heterozygous (NAT). Detected genotypes and clinical characteristics of these patients are given in Table III.

The NAT sample of a patient (number 4 in Table III) with different genotypes in both FII A19911G and FII G20210A variants was used for haplotype analysis. Analysis of the cloned sequence (a total of 16 clones were sequenced and analyzed) showed the presence of four different haplotypes in this tissue: 19911A-20210G, 19911A-20210A, 19911G20210G and 19911G-20210A.

\section{Discussion}

Besides its role in hemostasis, thrombin is known to affect different aspects of tumor biology; proliferation and migration of malignant cells, metastasis and angiogenesis (10). Studies on mice have shown that thrombin has a critical role in colon cancer growth and dissemination through stromal PAR-1 and fibrinogen (16). Analysis of human colon cancer samples determined the presence of Fragment F1+2, byproduct of prothrombin activation to thrombin, thus indirectly indicating the presence of prothrombin in tumor, although its origin still remains unclear (17). Prothrombin expression in colon cancer has been previously examined in few studies $(13,18)$. Dunjic et al. have examined whether cancer-derived cell lines express prothrombin. Results showed that Caco-2 cells, originating from colorectal adenocarcinoma, express prothrombin although in notably lower levels compared to the control liver sample (13). Besides the reported results, prothrombin expression and its regulation in colon cancer are still unclear.

Expression of the prothrombin gene is known to be significantly regulated by its 3 ' end, which is susceptible to gain-of-function variants that lead to increased prothrombin expression (12). In this study, we examined the presence of 3 ' end variations of the prothrombin gene in tumor and normal tissue adjacent to tumor in patients with colorectal adenocarcinoma. We detected three variants - FII G20210A, FII A19911G and FII c.1824C >T, in both types of tissues (Tables II and III). All three variants have been previously described and found to be associated with increased prothrombin expression $(12,19,20)$.

The FII G20210A gene variant is located in the 3' untranslated region of the prothrombin mRNA, at the position where the pre-mRNA is endonucleolytically cleaved and polyadenylated (12). It causes increased cleavage site recognition, increased 3 ' end processing and increased mRNA accumulation and protein synthesis (21). In Caucasians, G20210A is present with a frequency of 0.7 to $4 \%$, and an average of about $2 \%$ (22). In the Croatian population, its frequency is about $4 \%$ in patients with venous thromboembolism (VTE) and 6\% in healthy controls (23). In our study, we detected this variant in the heterozygous state in NAT samples in three patients (3.2\%). Among them, two patients were heterozygous carriers in the tumor tissue also, while one was a homozygous carrier. Vossen et al. have examined the correlation of clotting factor gene variants and colorectal cancer risk in a large German population-based case-control study, and found that heterozygous carriers of G20210A had a reduced risk compared to non-carriers (24). They considered that this might be due to the influence of the levels of thrombin on carcinogenesis, where low thrombin concentrations could exert protective effects by inducing endothelial barrier protection $(24,25)$.

The FII A19911G, a common gene variant located in the last intron of the prothrombin gene, is associated with slightly increased plasma prothrombin levels (19). This gene variant leads to higher splicing efficiency in the final intron, and also slightly increases the risk of thrombosis in carriers of the G20210A variation $(26,27)$. In our study, we detected this variant in $40.8 \%$ patients in the heterozygous state (one patient being heterozygous carrier of FII G20210A also), and in $24.7 \%$ patients in the homozygous state. Currently, there are no data regarding this variation frequency in the 
Croatian population. Data for the geographically and genetically close Serbian population (28) have shown that heterozygous and homozygous carriers in the healthy population are represented with frequencies of $50 \%$ and $18.3 \%$, respectively (29).

The FII c. $1824 \mathrm{C}>\mathrm{T}$ gene variant is located in the last exon of the prothrombin gene. It is considered as a synonymous variant, since it does not result in a change in the amino acid sequence of the protein. In vitro functional assays revealed that the FII c. $1824 \mathrm{C}>\mathrm{T}$ gene variant increased expression levels 1.64 times compared to the wild type, but the exact mechanism of overexpression has not yet been elucidated (20). In our study, we detected this variant only in one patient in the heterozygous state, who was also a heterozygous carrier of A19911G. This is the first report of this variant in the Croatian population.

Analysis of tumor tissue genotypes showed that four patients displayed different genotypes in the tumors compared to NAT (Table III). Since patients were heterozygous carriers in normal tissue and homozygous carriers/non-carriers in the tumor tissue, the transformation to tumor tissue could have been due to loss of heterozygosity (LOH) or de novo mutation. Loss of heterozygosity is one the most common features of cancer, with an average of $25-30 \%$ of alleles being lost (30). The gene encoding prothrombin is located in chromosome $11 \mathrm{p} 11.2$. The LOH on the long arm (31) and short arm (11p11) (32) of chromosome 11 has been previously described in colorectal cancer, but, to our knowledge, there are no data available on $\mathrm{LOH}$ regarding the prothrombin gene.

To further examine this, normal tissue of patient with changes in both FII A19911G and FII G20210A variants (Table III), was analyzed for haplotypes. Analysis of haplotypes showed a rather complex picture - there were four different haplotypes in only 16 analyzed clones: 19911A-20210G, 19911A-20210A, 19911G-20210G and 19911G-20210A. Some studies, concerning comparative analysis of different tumors and their normal adjacent tissue, concluded that NAT presents a unique intermediate state between tumor and healthy tissues (33).

To our knowledge, our study is the first to compare genotypes at the 3' end of prothrombin gene in tumor tissue and NAT in patients with colon adenocarcinoma. Though we detected a small number of patients with different tumor and NAT genotypes, which could be due to the size of our study group, existing differences in tissues' genotype in these patients could offer some information about the nature of colon cancer pathogenesis. Nevertheless, further and larger studies should be conducted to elucidate expression of this gene in malignant colon tissue and the relevant mechanisms, as well as to minutely examine its role in colon tumorigenesis. It is expected that the obtained findings will contribute to further elucidation of complex genotypephenotype correlations in patients suffering from this disease.

\section{Conflicts of Interest}

The Authors declare that there is no conflict of interest regarding this study.

\section{Authors' Contributions}

Cacev $\mathrm{T}$ and Djordjevic $\mathrm{V}$ were responsible for study design. Cacev $\mathrm{T}$ and Aralica $\mathrm{G}$ were responsible for sample and data collection. Jovanovic T, Cumbo $\mathrm{M}$ and Dunjic $\mathrm{S}$ and were responsible for experimental work. Tomic B, Gvozdenov M and Pruner I were responsible for data management and interpretation of results. Cumbo M, Tomic B and Djordjevic V were responsible for writing the manuscript. Kapitanovic S, Cacev T and Djordjevic V were responsible for supervision of the manuscript.

\section{Acknowledgements}

This work was supported by the Ministry of Education, Science and Technological Development of Republic of Serbia (No. 173008) and Bilateral-cooperation project between Republic of Serbia and Republic of Croatia "The role of prothrombin in colon cancer". The Authors are grateful to Dr. Aleksandra Nikolic for networking regarding the Bilateral-cooperation project.

\section{References}

1 Torre LA, Bray F, Siegel RL, Ferlay J, Lortet-Tieulent J and Jemal A: Global cancer statistics, 2012. CA Cancer J Clin 65(2): 87-108, 2015. PMID: 25651787. DOI: 10.3322/caac.21262

2 Fleming M, Ravula S, Tatishchev SF and Wang HL: Colorectal carcinoma: Pathologic aspects. J Gastrointest Oncol 3(3): 153173, 2012. PMID: 22943008. DOI: 10.3978/j.issn.2078-6891. 2012.030

3 Yamagishi H, Kuroda H, Imai Y and Hiraishi H: Molecular pathogenesis of sporadic colorectal cancers. Chin J Cancer 35: 4, 2016. PMID: 26738600. DOI: 10.1186/s40880-015-0066-y

4 Rees PA, Clouston HW, Duff S and Kirwan CC: Colorectal cancer and thrombosis. Int J Colorectal Dis 33(1): 105-108, 2018. PMID: 29127473. DOI: 10.1007/s00384-017-2909-2

5 Iversen LH and Thorlacius-Ussing O: Relationship of coagulation test abnormalities to tumour burden and postoperative DVT in resected colorectal cancer. Thromb Haemost 87(3): 402-408, 2002. PMID: 11916070.

6 Gouin-Thibault I, Achkar A and Samama MM: The thrombophilic state in cancer patients. Acta Haematol 106(1-2): 33-42, 2001. PMID: 11549775. DOI: 10.1159/000046587

7 Crawley JT, Zanardelli S, Chion CK and Lane DA: The central role of thrombin in hemostasis. J Thromb Haemost 5(Suppl 1): 95-101, 2007. PMID: 17635715 . DOI: 10.1111/j.1538-7836.2007.02500.x

8 Coughlin SR: Thrombin signalling and protease-activated receptors. Nature 407(6801): 258-264, 2000. PMID: 11001069. DOI: $10.1038 / 35025229$

9 Tsopanoglou NE and Maragoudakis ME: Role of thrombin in angiogenesis and tumor progression. Semin Thromb Hemost 30(1): 63-69, 2004. PMID: 15034798. DOI: 10.1055/s-2004-822971

10 Wojtukiewicz MZ, Hempel D, Sierko E, Tucker SC and Honn $\mathrm{KV}$ : Thrombin-unique coagulation system protein with multifaceted impacts on cancer and metastasis. Cancer Metastasis 
Rev 35(2): 213-233, 2016. PMID: 27189210. DOI: $10.1007 /$ s10555-016-9626-0

11 Marder V, Aird W, Bennett J, Schulman S and White G: Hemostasis and thrombosis: basic principles and clinical practice. sixth edn. Lippincott Williams \& Wilkins: Philadelphia, PA, USA, 2013

12 Danckwardt S, Gehring NH, Neu-Yilik G, Hundsdoerfer P, Pforsich M, Frede U, Hentze MW and Kulozik AE: The prothrombin 3'end formation signal reveals a unique architecture that is sensitive to thrombophilic gain-of-function mutations. Blood 104(2): 428-435, 2004. PMID: 15059842. DOI: 10.1182/blood2003-08-2894

13 Dunjic S, Cumbo M, Gvozdenov M, Tomic B, Pruner I, Radojkovic D and Djordjevic V: Prothrombin expression in cancer-derived cell lines. Arch Biol Sci 71(1): 49-54, 2019. DOI: 10.2298/ABS180829046D

14 Spaventi R, Pecur L, Pavelic K, Pavelic ZP, Spaventi S and Stambrook PJ: Human tumour bank in Croatia: A possible model for a small bank as part of the future european tumour bank network. Eur J Cancer 30A(3): 419, 1994. PMID: 8204375. DOI: 10.1016/0959-8049(94)90277-1

15 Sambrook J: Molecular Cloning. A Laboratory Manual. Cold Spring Harbor, USA: Cold Spring Harbor Laboratory Press, 1989.

16 Adams GN, Rosenfeldt L, Frederick M, Miller W, Waltz D, Kombrinck K, McElhinney KE, Flick MJ, Monia BP, Revenko AS and Palumbo JS: Colon cancer growth and dissemination relies upon thrombin, stromal PAR-1, and fibrinogen. Cancer Res 75(19): 4235-4243, 2015. PMID: 26238780. DOI: 10.1158/0008-5472.CAN-15-0964

17 Sierko E, Wojtukiewicz MZ, Zimnoch L, Thorpe PE, Brekken RA and Kisiel W: Co-localization of prothrombin fragment F1+2 and VEGF-R2-bound VEGF in human colon cancer. Anticancer Res 31(3): 843-847, 2011. PMID: 21498704.

18 Uhlén M, Fagerberg L, Hallström BM, Lindskog C, Oksvold P, Mardinoglu A, Sivertsson Å, Kampf C, Sjöstedt E, Asplund A, Olsson I, Edlund K, Lundberg E, Navani S, Szigyarto CA, Odeberg J, Djureinovic D, Takanen JO, Hober S, Alm T, Edqvist $\mathrm{PH}$, Berling $\mathrm{H}$, Tegel $\mathrm{H}$, Mulder $\mathrm{J}$, Rockberg J, Nilsson $\mathrm{P}$, Schwenk JM, Hamsten M, von Feilitzen K, Forsberg M, Persson L, Johansson F, Zwahlen M, von Heijne G, Nielsen J and Pontén F: Proteomics. Tissue-based map of the human proteome. Science 347(6220): 1260419, 2015. PMID: 25613900. DOI: $10.1126 /$ science. 1260419

19 Ceelie H, Bertina RM, van Hylckama Vlieg A, Rosendaal FR and Vos HL: Polymorphisms in the prothrombin gene and their association with plasma prothrombin levels. Thromb Haemost 85(6): 1066-1070, 2001. PMID: 11434686. DOI: $10.1055 / \mathrm{s}$ 0037-1615965

20 Djordjevic V, Pruner I, Kovac M, Miljic P, Antonijevic N, Kojic $\mathrm{S}$ and Radojkovic D: Three novel 3' end pro-thrombin gene polymorphisms and their association with thrombophilia (abstract). J Thromb Haemost 9(2): 873S, 2011. DOI: 10.1111/j.1538-7836.2011.04380_4.x

21 Gehring NH, Frede U, Neu-Yilik G, Hundsdoerfer P, Vetter B, Hentze MW and Kulozik AE: Increased efficiency of mRNA 3' end formation: A new genetic mechanism contributing to hereditary thrombophilia. Nat Genet 28(4): 389-392, 2001. PMID: 11443298. DOI: $10.1038 / \mathrm{ng} 578$

22 Rosendaal FR, Doggen CJ, Zivelin A, Arruda VR, Aiach M, Siscovick DS, Hillarp A, Watzke HH, Bernardi F, Cumming AM,
Preston FE and Reitsma PH: Geographic distribution of the $20210 \mathrm{G}$ to A prothrombin variant. Thromb Haemost 79(4): 706708, 1998. PMID: 9569177.

23 Alfirevic Z, Simundic A, Nikolac N, Sobocan N, Alfirevic I, Stefanovic M, Vucicevic Z and Topic E: Frequency of factor II G20210A, factor V Leiden, MTHFR C677T and PAI-1 5G/4G polymorphism in patients with venous thromboembolism: Croatian case-control study. Biochemia Medica 20: 229-235, 2010. DOI: $10.11613 / \mathrm{BM} .2010 .028$

24 Vossen CY, Hoffmeister M, Chang-Claude JC, Rosendaal FR and Brenner $\mathrm{H}$ : Clotting factor gene polymorphisms and colorectal cancer risk. J Clin Oncol 29(13): 1722-1727, 2011. PMID: 21422408. DOI: 10.1200/JCO.2010.31.8873

25 Feistritzer $\mathrm{C}$ and Riewald M: Endothelial barrier protection by activated protein $\mathrm{C}$ through PAR1-dependent sphingosine 1phosphate receptor-1 crossactivation. Blood 105(8): 3178-3184, 2005. PMID: 15626732. DOI: 10.1182/blood-2004-10-3985

26 von Ahsen $\mathrm{N}$ and Oellerich $\mathrm{M}$ : The intronic prothrombin 19911A $>$ G polymorphism influences splicing efficiency and modulates effects of the $20210 \mathrm{G}>\mathrm{A}$ polymorphism on mRNA amount and expression in a stable reporter gene assay system. Blood 103(2): 586-593, 2004. PMID: 14504098. DOI: 10.1182/blood-2003-02-0419

27 Pérez-Ceballos E, Corral J, Alberca I, Vayá A, Llamas P, Montes R, González-Conejero R and Vicente V: Prothrombin A19911G and G20210A polymorphisms' role in thrombosis. Br J Haematol 118(2): 610-614, 2002. PMID: 12139755. DOI: 10.1046/j.1365$2141.2002 .03624 . \mathrm{x}$

28 Kovacevic L, Tambets K, Ilumäe AM, Kushniarevich A, Yunusbayev B, Solnik A, Bego T, Primorac D, Skaro V, Leskovac A, Jakovski Z, Drobnic K, Tolk HV, Kovacevic S, Rudan P, Metspalu E and Marjanovic D: Standing at the gateway to Europe--the genetic structure of western Balkan populations based on autosomal and haploid markers. PLoS One 9(8): e105090, 2014. PMID: 25148043. DOI: 10.1371/journal.pone.0105090

29 Djordjevic V, Pruner I, Tomic B, Nestorovic A, Gvozdenov M, Kovac $\mathrm{M}$ and Radojkovic D: The 3'end prothrombin gene variants in patients with different thrombotic events. Lab Med 45(4): 309-314, 2014. PMID: 25316662. DOI: 10.1309/LM8E84 ZSLPDMWZCM

30 Pino MS and Chung DC: The chromosomal instability pathway in colon cancer. Gastroenterology 138(6): 2059-2072, 2010. PMID: 20420946. DOI: 10.1053/j.gastro.2009.12.065

31 Tomlinson IP and Bodmer WF: Chromosome 11q in sporadic colorectal carcinoma: Patterns of allele loss and their significance for tumorigenesis. J Clin Pathol 49(5): 386-390, 1996. PMID: 8707952. DOI: 10.1136/jcp.49.5.386

32 Ruivenkamp C, Hermsen M, Postma C, Klous A, Baak J, Meijer $\mathrm{G}$ and Demant P: LOH of PTPRJ occurs early in colorectal cancer and is associated with chromosomal loss of 18q12-21. Oncogene 22(22): 3472-3474, 2003. PMID: 12776199. DOI: 10.1038/sj.onc. 1206246

33 Aran D, Camarda R, Odegaard J, Paik H, Oskotsky B, Krings G, Goga A, Sirota M and Butte AJ: Comprehensive analysis of normal adjacent to tumor transcriptomes. Nat Commun 8(1): 1077, 2017. PMID: 29057876. DOI: 10.1038/s41467-017-01027-z

Received September 18, 2019

Revised October 7, 2019

Accepted October 8, 2019 